Artigo original

Hegemonia - Revista Eletrônica do Programa de Mestrado em Direitos Humanos, Cidadania e Violência/Ciência Política do Centro Universitário Unieuro

ISSN: $1809-1261$

UNIEURO, Brasília, número 25 (Especial), 2018, pp. 106-136.

Recebido em: 10/04/2018

Avaliado em: 15/05/2018

Aprovado em: 30/05/2018

\title{
MEDICAL DEVICE DESIGN: CONSIDERATIONS FOR GLOBALLY- FOCUSED INNOVATION
}

\author{
Melina Lynn, ${ }^{1}$ Matt Hannula, ${ }^{2}$ and Icaro dos Santos ${ }^{3}$
}

Abstract: The disparity in appropriate healthcare technologies between developed and developing countries is one of the greatest issues facing the global quality of healthcare today. While hospitals in developing countries boast cutting edge-life saving healthcare technologies, many healthcare facilities in the developing world do not have access to even the most rudimentary supplies and technologies to treat patients. This mismatch results from a number of shortcomings across the medical device industry and represents a failure of new healthcare technologies to reach their full potential. This paper aims to promote awareness of the healthcare technology disparity and provide recommendations for the design and implementation of medical devices for the global market.

Key-words: Promoting Awareness, Healthcare Technology Management, Technical Design Considerations

Resumo: A disparidade em tecnologias de saúde apropriadas entre países desenvolvidos e em desenvolvimento é um dos maiores problemas enfrentados atualmente pela qualidade global da saúde. Enquanto os hospitais nos países em desenvolvimento possuem tecnologias de cuidados de saúde de ponta, muitas instalações de cuidados de saúde nos países em desenvolvimento não têm acesso às fontes e tecnologias mais rudimentares para $\mathrm{O}$ tratamento de pacientes. Esse descompasso resulta de uma série de deficiências na indústria de dispositivos médicos e representa uma falha de novas tecnologias de assistência médica para atingir seu pleno potencial. Este artigo tem como objetivo promover a conscientização sobre a disparidade da tecnologia de saúde e fornecer recomendações para o projeto e implementação de dispositivos médicos para o mercado global.

Palavras-chave: Promovendo Conscientização, Gestão de Tecnologia em Saúde, Considerações Técnicas de Design

\footnotetext{
${ }^{1}$ Eh Milwaukee School of Engineering

2 Eh Milwaukee School of Engineering

${ }^{3}$ Eh Milwaukee School of Engineering
} 
Artigo original

Hegemonia - Revista Eletrônica do Programa de Mestrado em Direitos Humanos, Cidadania e Violência/Ciência Política do Centro Universitário Unieuro

ISSN: $1809-1261$

UNIEURO, Brasília, número 25 (Especial), 2018, pp. 106-135.

Section 1: Introduction

Developed World

Highly developed nations such as the U.S., Japan, and many European countries have effectively established a standard of healthcare that ensures consistent, safe delivery of care universally. The welldeveloped structure and financial stability of healthcare in such nations ensures the availability of treatment, along with the appropriate medical technology, supplies, and clinical support required for that treatment. This level of care, consistent and expected by citizens of developed nations, allows for future growth of healthcare technology into cutting-edge fields and high-tech research. The advanced technical capabilities of these nations have served as the central driving force for the progress of the healthcare industry over the last decade.

Valued at more than $\$ 140$ billion in 2015 , the United States medical device market alone has invested considerable amounts into research and development, establishing itself as a leader in the "advancement in innovative and developed technologies" [1]. Globally, the medical device market is projected to grow to $\$ 435.8$ billion, with an emphasis on computer-related technology including information technology, molecular medicine including tissue and genetic engineering, and alternative drug delivery methods [1,2]. These developments indicate great promise for the treatment and diagnosis of the conditions that present the greatest threat to developed nation populations.

As with all medical advancement, the goal of developing new technologies is to improve patient outcomes. In developed nations, this includes the diagnosis of mental disorders, management of chronic conditions like chronic obstructive pulmonary disease and diabetes, along with treatment of cancer [2]. Addressing such conditions through the technologies mentioned earlier is the goal of most medical device manufacturing and research in the developed world. These developed nations spent $97 \%$ of the $\$ 160.3$ billion global health research and development budget in 2005 to "generate 
Artigo original

Hegemonia - Revista Eletrônica do Programa de Mestrado em Direitos Humanos, Cidadania e Violência/Ciência Política do Centro Universitário Unieuro

ISSN: $1809-1261$

UNIEURO, Brasília, número 25 (Especial), 2018, pp. 106-135.

products, processes, and service for their own health care markets, which have little in common with the needs of low-income settings" [3].

Developing World

While new technologies save thousands of lives in developed nations, healthcare facilities in the developing world have been left in the dark. Such facilities are isolated not only in terms of resources and support, but are further dissociated from the global medical device market due to the misinformation and stereotypes surrounding their situation by those dominating the market. In order to move forward in developing medical technologies to meet the unique needs of developing countries, their environment and difficulties in healthcare delivery must be properly understood.

In order to understand the condition of healthcare facilities in developing countries, one must set aside their personal healthcare experiences in developed countries along with their previous misconceptions about resource-poor environments. Developing countries have healthcare systems with hospitals, clinical staff, and medical technology. These resources, however, take on a starkly different form than the same resources in developed countries. In many developing countries, less money is spent on their entire health budget than intensive care medicine alone in developed nations [4]. Staffing in such hospitals also suffers due to the lack of funds and the "brain drain" phenomenon as skilled clinicians seek employment in richer countries [4]. There is a constant state of inadequate funding in many district hospitals, which often leads to inadequate supplies and sub-par medical devices. According to the World Health Organization [5], "the majority of the world's population is denied adequate access to safe and appropriate medical devices within their health systems." When it comes to devices in public, low-resource hospitals, over $95 \%$ of the medical equipment is imported, with a large proportion donated from developed nations [6].

As in developed country hospitals, training clinical staff on medical device use is a constant battle. Developed nation hospitals often have an extensive engineering team, proper manuals, along with customer service and service contract support for their medical devices. In developing nations, 
Artigo original

Hegemonia - Revista Eletrônica do Programa de Mestrado em Direitos Humanos, Cidadania e Violência/Ciência Política do Centro Universitário Unieuro

ISSN: $1809-1261$

UNIEURO, Brasília, número 25 (Especial), 2018, pp. 106-135.

however, public hospitals are lucky to have a basic technician and a manual in a different language, if at all. This lack of support leads to improper use of devices and accelerated breakdown of the devices. As in a study of 1,289 pieces of equipment donated to Colombia, 39\% of the equipment never worked due to insufficient training and missing accessories or manuals [6].

One of the unique troubles in developing nations, which is widely overlooked by first-world citizens and medical device developers, is the availability of disposable supplies [Malkin]. Deemed a lucrative and hygienic option in their countries of origin, consumables are simply unaffordable or inaccessible in developing countries. Items as simple as disposable gloves or ultrasound gel are limited and must be reused or replaced by a locally sourced, cheaper option, which may or may not exist.

The infrastructure in developing nations also limits the availability of supplies such as clean water, oxygen, vaccines along with safe, reliable transportation. As a necessity in proper healthcare delivery, the mismatch between supply and demand of medical oxygen will be explored later in this chapter. It should be noted as one of the greatest insufficiencies in developing world medicine.

While a clear disparity exists in the access to healthcare technologies between healthcare facilities in developed and developing countries, there is likely no clear solution on which all parties involved will agree. While other sources have cited more complicated and comprehensive strategies, this paper aims to promote a strategy that targets three of the primary failures in the medical device sphere that initiated or amplified this issue. The aforementioned failures are simplified into three categories - (1) a lack of awareness of or motivation to correct the disparity, (2) failure to adequately assess a technology's appropriateness, and (3) technical failures in the design of devices for use in these lowresource environments. 
Artigo original

Hegemonia - Revista Eletrônica do Programa de Mestrado em Direitos Humanos, Cidadania e Violência/Ciência Política do Centro Universitário Unieuro

ISSN: $1809-1261$

UNIEURO, Brasília, número 25 (Especial), 2018, pp. 106-135.

\section{Section 2: Solutions}

The proposed solutions are appropriately centered around (1) promoting awareness among citizens, governments, and the medical device industry, (2) implementing improved Health Technology Assessments both in developing world healthcare facilities and by medical device manufactures, and (3) suggesting design strategies for use in low-resource healthcare facilities.

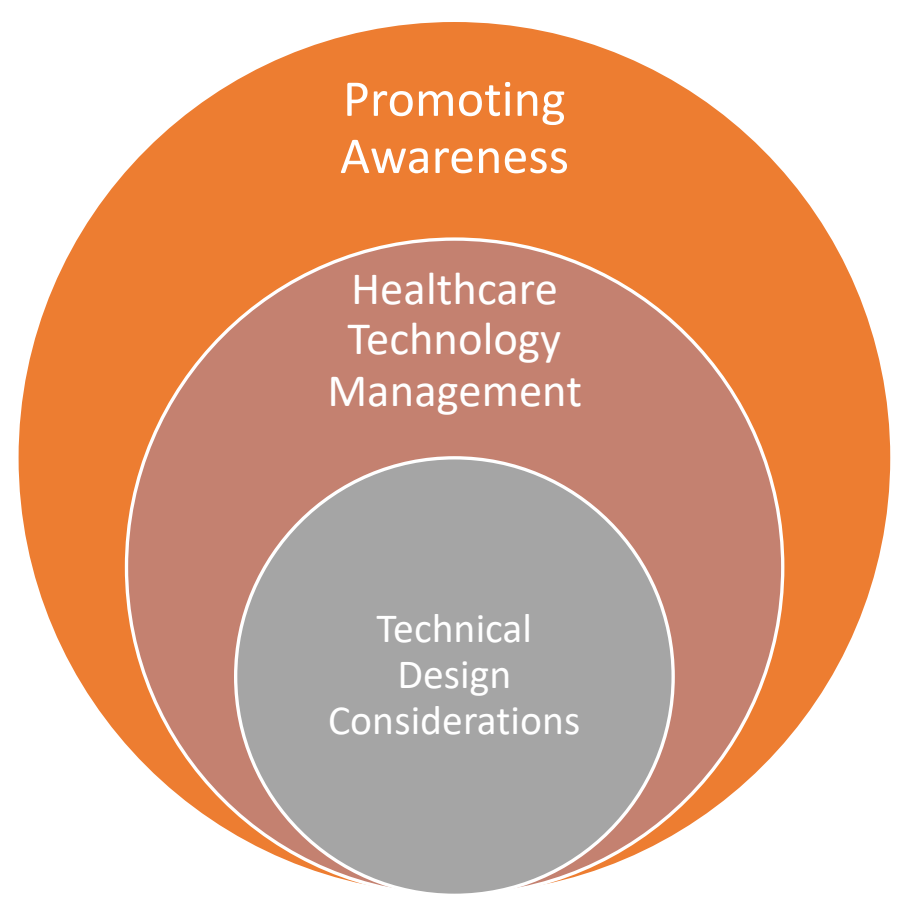

Figure 1 - Closing the gap: a three-headed approach to improving the availability of healthcare technologies in the developing world.

Education and Awareness

The first step in the process towards reducing the technology gap between developed and developing countries is education. There exists an individual and organizational lack of awareness or apathy 
Artigo original

Hegemonia - Revista Eletrônica do Programa de Mestrado em Direitos Humanos, Cidadania e Violência/Ciência Política do Centro Universitário Unieuro

ISSN: $1809-1261$

UNIEURO, Brasília, número 25 (Especial), 2018, pp. 106-135.

towards this issue in both the public and the medical device industry. Education is a necessary step, as it allows individuals who were previously unaware of the issue to join the conversation and collaborate to develop solutions. While many people are largely unaware of these issues, others are simply apathetic towards it. These individuals can also be reached. By promoting awareness and beginning an involved discussion of these issues, many will be encouraged to take action.

Promoting Industry Awareness

A health technology is defined as "any intervention that may be used to promote health, to prevent, diagnose, treat disease, or for rehabilitation or long-term care" [7]. Thus, the purpose of any healthcare technology is to aid healthcare professionals in treating patients more effectively and to improve patient outcomes. While some of the factors negatively affecting healthcare technologies in the developing world can be attributed to improper management of technology by the recipients and endusers, the burden also rests on the shoulders of the medical device manufacturers. The vast majority of new technologies fail to reach their full potential as they are designed in a way that prevents effective use in many healthcare facilities around the world. This prevents billions of patients from receiving essential care. Clearly, medical device manufacturers do not intentionally promote unequal distribution of healthcare technology; however, they amplify the issue through inaction.

There are myriad reasons that medical device manufacturers do not design technologies to be used in developing world healthcare facilities. One such reason is the many design considerations that must be made for devices to operate effectively in these healthcare facilities (e.g. lack of proper power infrastructure, hot and dusty environments within the facilities, lack of trained maintenance staff, userinterface errors). Additionally, these facilities operate on extremely limited budgets and very often cannot afford new equipment directly from the manufacturers. As prices are dictated by the amount invested to bring the device to market, it is sometimes financially unfeasible for the manufacturers to focus on the developing world market. It is convenient for medical device manufacturers to ignore this smaller, more challenging market, especially as large, well-funded healthcare facilities in the developed world are continuously requesting and purchasing new products. 
Artigo original

Hegemonia - Revista Eletrônica do Programa de Mestrado em Direitos Humanos, Cidadania e Violência/Ciência Política do Centro Universitário Unieuro

ISSN: $1809-1261$

UNIEURO, Brasília, número 25 (Especial), 2018, pp. 106-135.

This is not to say that no medical device manufacturers have brought appropriate products to market. A number of large and small organizations have taken steps to develop appropriate globally focused technologies. As of 2015, GE Healthcare had invested more than $\$ 120$ million in healthcare facilities across Latin America, Africa, and Southeast Asia as part of a program beginning in 2014. GE has also developed a portable ultrasound system for front-line healthcare workers to improve maternal health in developing countries and remote settings [8] and has produced CT systems specifically designed for use in low-resource environments [9]. Another example is Gradian Health Systems, which produces the durable, intuitive Universal Anesthesia Machine that has saved many lives by providing sustainable anesthesia in developing world healthcare facilities [10]. It is critical that companies look to these examples and take the initiative to develop similar life-saving technologies. While there are additional technical challenges and lower profits associated with these designs, global health impact is immense. As organizations gain awareness and can look to the example of other large organizations, more and more medical device startups and large manufacturers can follow in the same footsteps. In the end, improving the health and livelihood of individuals in these developing nations serves as an investment in these regions - improving the overall health of the region will likely have positive economic effects and continue to grow the market for medical devices and healthcare technology.

Of paramount importance is promoting awareness among individuals within the medical device industry. It is critical that individuals - executives, engineers, and supporting function roles - within the medical device industry recognize the importance of these issues. Without this critical step, it is unlikely that the industry will move to develop appropriate technologies to solve these global health problems. Of particular importance is the formal education of executives and decision-makers within the medical device industry on the global needs in healthcare and medical device design. Additionally, it is necessary to educate engineers within the medical device industry on how to design appropriate technology for the developing world. The last section of this paper introduces some of these critical design considerations. The establishment of formal education programs for engineers in this field would be an incredible step towards a long-term solution. Educating decision-makers and engineers on specific ways to approach these technical challenges may encourage them to begin the development of these life-saving technologies. In many cases, existing devices can be modified to provide sustainable solutions to widespread needs - these and other considerations will be discussed in detail. 
Artigo original

Hegemonia - Revista Eletrônica do Programa de Mestrado em Direitos Humanos, Cidadania e Violência/Ciência Política do Centro Universitário Unieuro

ISSN: $1809-1261$

UNIEURO, Brasília, número 25 (Especial), 2018, pp. 106-135.

Promoting Government Awareness

While the involvement of medical device manufacturers is perhaps the most critical step in working towards closing the gap, the appropriate involvement of governing bodies is required for a sustainable solution. Governing bodies in both developed and developing countries play a role in this process through the proper implementation of Health Technology Assessments and through encouragement of medical device manufacturers to follow through on their designs to make them more appropriate for use in these environments. First, it is important for the governments of developing countries to collaborate with international organizations and other nations to implement a proper Health Technology Assessment (HTA) program. Health Technology Assessment is defined as "the systematic evaluation of properties, effects, and/or impacts of health-care technology" [7]. HTA generally is used to refer to large-scale assessments informing governmental technology-related policy-making. In this paper, HTA will also be extended to describe the holistic assessment performed by medical device manufacturers to understand the market for and impact of new healthcare technologies. While national governments already have established HTA programs, implementation within the regional and local government as well as in the healthcare facilities is critical. A nationally standardized HTA program can be used to inform healthcare facilities on best practices and will allow the government to better understand the status and needs of the country's healthcare facilities. Additionally, improved awareness within the governments of developed countries allows government officials to move towards creating programs that encourage medical device manufacturers to take action against this issue. For example, programs which encourage manufacturers to follow through on previous designs to make them suitable for developing world applications. Further discussions of these issues also allows informed government officials to work directly with international organizations (i.e. the World Health Organization) and other governments to develop strategies to solve these global health issues. 
Artigo original

Hegemonia - Revista Eletrônica do Programa de Mestrado em Direitos Humanos, Cidadania e Violência/Ciência Política do Centro Universitário Unieuro

ISSN: $1809-1261$

UNIEURO, Brasília, número 25 (Especial), 2018, pp. 106-135.

Promoting Public Awareness

While public education on this issue has no direct effect on national or organizational policies affecting healthcare technology, it is a necessary step in moving towards a long-term solution. It is not the aim of this paper to suggest specific educational strategies, but rather to promote the notion that without knowledge of a problem, the public cannot take action towards a solution. As will be discussed later in this paper, an understanding of the cultural, environmental, clinical and technical challenges are critical in developing technologies that bridge the gap between healthcare facilities in developed and developing countries. Though important through all levels of education, it is of particular importance for technical university-level programs (i.e. engineering) to educate students on these economic and health-related disparities as well as the necessary cultural considerations in globally focused design. The current technology disparity demonstrates that technical education alone is not enough educating well-rounded and globally aware professionals is a critical step in working towards a solution.

The majority of citizens in developed countries, even those working in the healthcare field, are unaware of the severity of the healthcare technology imbalance. While the majority of individuals are aware of socioeconomic disparities that exist between developed and developing countries, many are unaware of their severity or reach. Of those who are aware, most are uninformed - or misinformed on how best to help. Public education on these issues opens the conversation to a new audience and creates a platform upon which the creative, passionate leaders of the next generation can stand to develop both small- and large-scale solutions to these issues affecting global health.

One of the primary benefits of an informed public is in reducing the donation of improper medical equipment to developing world healthcare facilities. In many developed countries, it is common for hospitals, clinics, and individuals to donate used medical devices and unexpired medical supplies to developing world healthcare facilities. While many small, resource-poor healthcare facilities are in desperate need of appropriate equipment and supplies, much of the donated equipment is inappropriate and may even represent a burden on the recipient. For example, inappropriate medical devices are those that require regular maintenance that is unavailable, rely upon resources that are not 
Artigo original

Hegemonia - Revista Eletrônica do Programa de Mestrado em Direitos Humanos, Cidadania e Violência/Ciência Política do Centro Universitário Unieuro

ISSN: $1809-1261$

UNIEURO, Brasília, número 25 (Especial), 2018, pp. 106-135.

always available (i.e. constant electricity), or require advanced user training that is not available within the region [11]. According to the World Health Organization, while some facilities acquire nearly 80\% of their equipment through donations, only 10-30\% of donated equipment becomes operational [12]. As many facilities do not properly manage their technology, they are unable to properly assess incoming equipment and are ultimately unaware of the operational and maintenance requirements of the technology they receive.

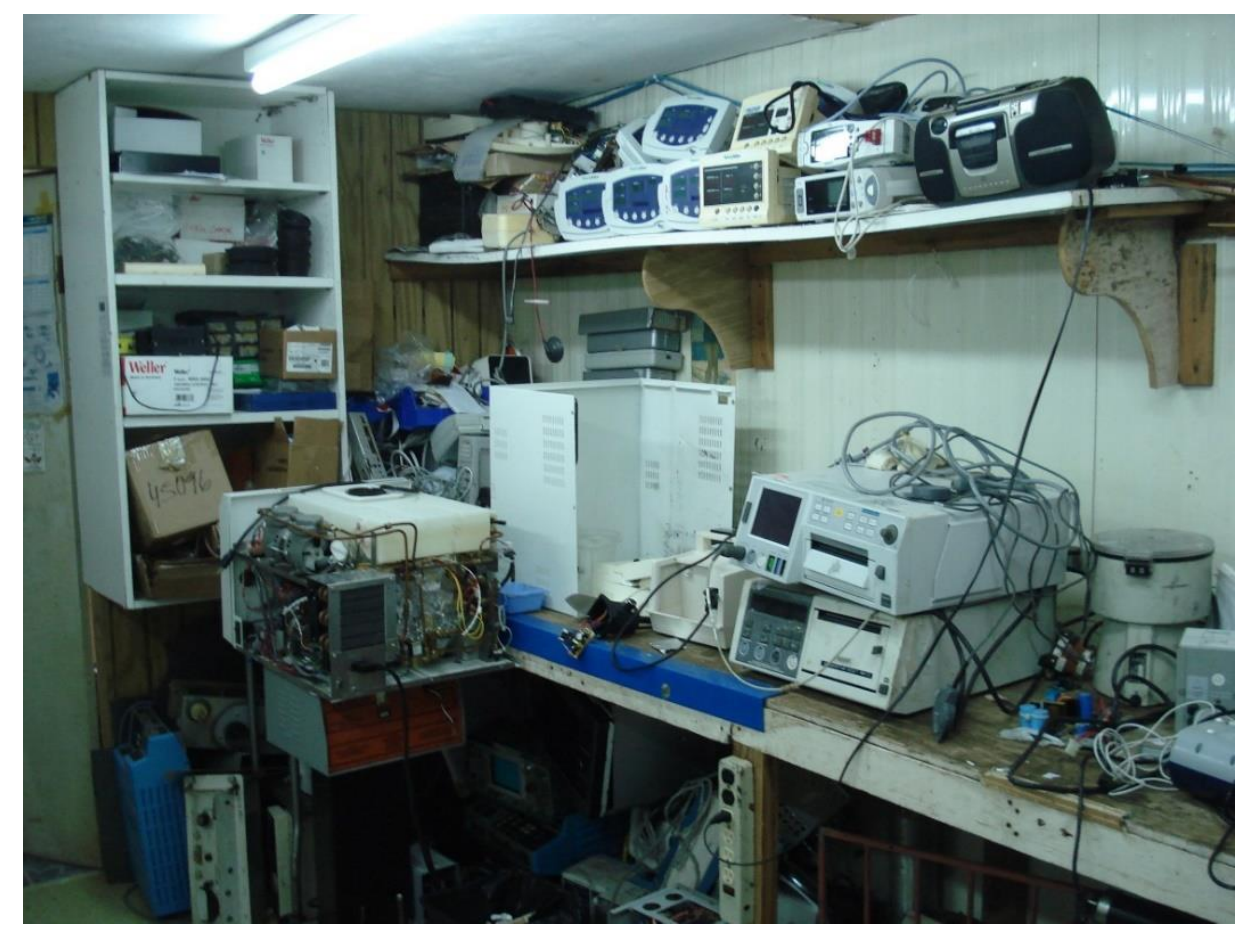

Figure 2 - Most donated medical devices never become operational and ultimately become a burden on developing world healthcare facilities [13].

The donation of improper equipment burdens these facilities in a number of ways. First, facilities can directly lose money in cases where they must pay for the delivery of the inappropriate equipment. These facilities may also be burdened by extremely high operating or repair costs of unnecessary equipment (especially for large, sensitive equipment such as X-ray, CT, and MRI machines). 
Artigo original

Hegemonia - Revista Eletrônica do Programa de Mestrado em Direitos Humanos, Cidadania e Violência/Ciência Política do Centro Universitário Unieuro

ISSN: $1809-1261$

UNIEURO, Brasília, número 25 (Especial), 2018, pp. 106-135.

Inappropriate equipment donations also present a burden on the space and efficiency of healthcare facilities as broken, misused, or misunderstood equipment litters the property, hallways, storage spaces, and clinical workspace. Many healthcare facilities often are afraid to discard old equipment in case they might need the broken equipment sometime in the future.

This issue will continue to plague healthcare facilities in the developing world as long as organizations and individuals remain unaware of their faults. Proper public education can also reduce the donation of improper equipment in cases that the fault is attributed to the requests of developing world healthcare facilities. Informed donating institutions are better equipped to communicate with the facilities to help determine whether the request will be beneficial or harmful to the recipient facility.

Assessing and Managing Health Technology

Proper Health Technology Assessment (HTA) and Management (HTM) is essential in all aspects of healthcare. Hospitals must manage available equipment and make appropriate considerations when new equipment is procured. Medical device manufacturers use a similar process to assess the needs of healthcare providers as well as the operation environment and economic aspects of the medical devices they develop. Finally, governments perform extensive Health Technology Assessments to develop health-related regulations based on the clinical, economic, ethical, and societal impacts of health technologies.

Medical Device Industry

To a greater extent than many other industries, medical device manufacturers must understand existing technologies, clinical needs, and regulatory benchmarks associated with any technology they develop. These manufacturers perform extensive studies consistent with a Health Technology Assessment to analyze the market, determine a device's feasibility, and navigate the regulatory pathway. This analysis 
Hegemonia - Revista Eletrônica do Programa de Mestrado em Direitos Humanos, Cidadania e Violência/Ciência Política do Centro Universitário Unieuro

ISSN: $1809-1261$

UNIEURO, Brasília, número 25 (Especial), 2018, pp. 106-135.

ensures that new devices brought to market in developed countries are demonstrably safe, effective, and appropriate in their intended environment. Unfortunately, this analysis is rarely extended to the developing world setting - neither by major medical device companies nor by many of the small companies designing medical products for the developing world. Each of these groups will be discussed individually to highlight the ramifications of the failure to extend Technology Assessments to the developing world. Figure 3 shows a functional breakdown of the primary considerations to be made during an HTA.

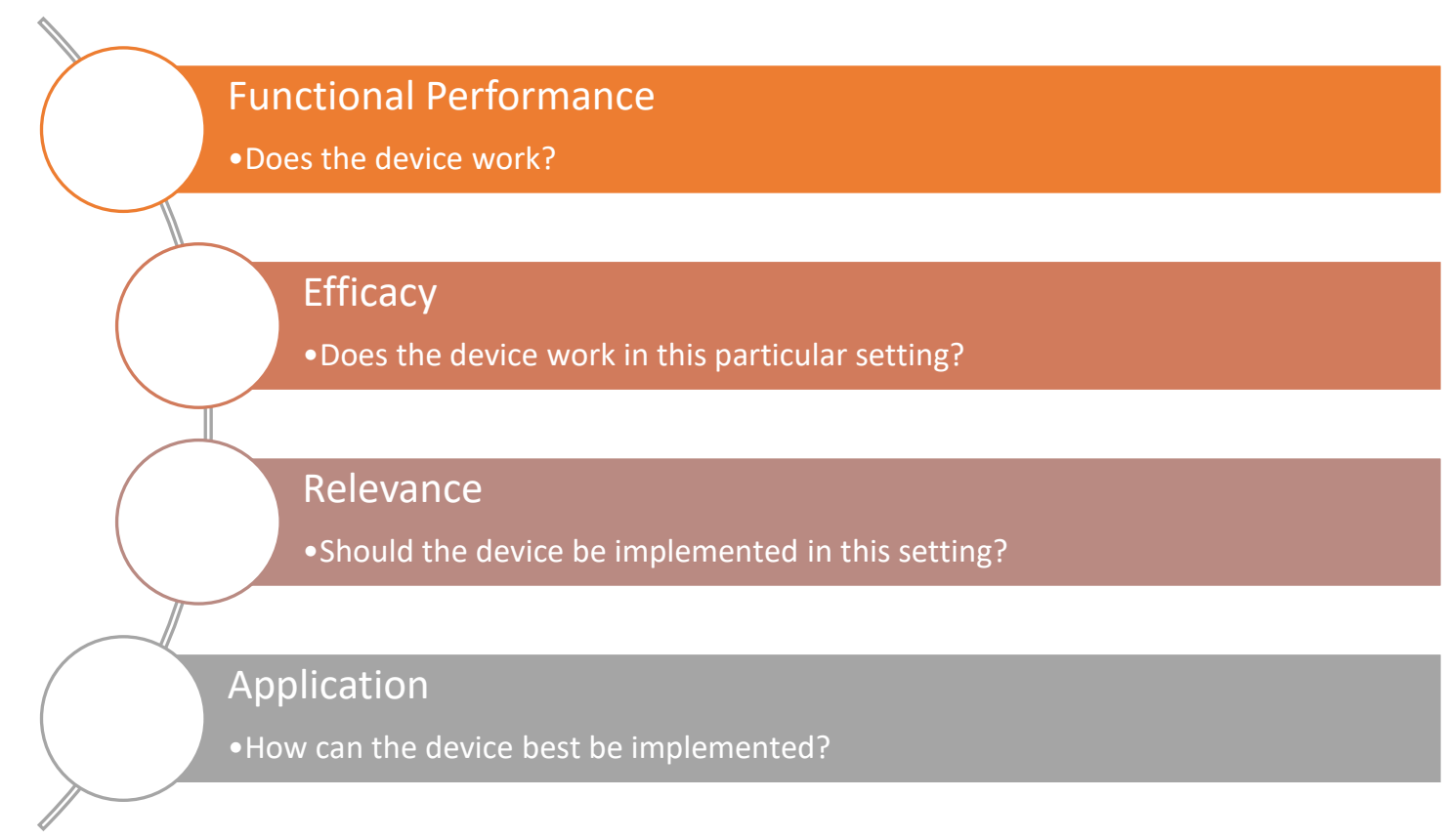

Figure 3 - Considerations in Technology Assessment for a medical device manufacturer (adapted from WHO).

As most medical devices are not intended for use in developing countries, manufacturers do not extend the Technology Assessment process to the developing world market. While it sounds counterintuitive to suggest that these manufacturers assess the technology's use in the developing world market, this process would likely change the design mindset and lead to the development of many new, appropriate medical devices for this market. In many cases, particularly with small medical 
Artigo original

Hegemonia - Revista Eletrônica do Programa de Mestrado em Direitos Humanos, Cidadania e Violência/Ciência Política do Centro Universitário Unieuro

ISSN: $1809-1261$

UNIEURO, Brasília, número 25 (Especial), 2018, pp. 106-135.

devices, the operating mechanism functions just as well in developing countries as in the intended market. In these cases, the primary factors limiting the appropriateness of the technology are often related to the power distribution, environmental durability, and user experience. In many cases, the solutions to these issues are relatively straightforward and, if considered in the initial design, can largely be addressed from the outset. For example, by designing the device to be intuitively serviceable with limited tools, eliminating the use of disposables, and removing all sensitive and unnecessary electronics (i.e. excessive screens), one can make a small medical device far more appropriate for use in the developing world. As an additional example, many medical devices intended for home-use are naturally better suited for use in the developing world because they were initially designed to be used in a non-clinical setting. Special design considerations are made from the outset, including increased durability, improved serviceability, and an intuitive user interface for an untrained/non-clinical user. While all medical devices are designed with these considerations, they must be a central focus in both home-health and developing world designs. This demonstrates that when considered in the initial design, these additional requirements are certainly manageable in many cases.

If medical device manufacturers extend traditional Technology Assessments to the developing world, it will likely shed light on a plethora of devices needed in the developing world The key to this process is in changing one's mindset during the design process. While the developing world is still not the primary intended market of the technology, it exists in the back of the minds of those involved.

While some medical device startups and manufacturers developing healthcare technologies intended for use in developing world healthcare facilities, many of these solutions are still inappropriate or inadequate for use in their intended environment. This often results from a failure to perform an adequate Technology Assessment and to understand the cultural considerations associated with the implementation of their technology. The World Health Organization cites the failure of an affordable wooden-seat wheelchair - otherwise well designed for the region - to replace wheelchairs from highresource settings that had tires and other unnecessary features. Despite its design to fold and fit through narrow doorways and other hard to access areas, most people could not afford to replace the pad on the seat, which wore out quickly and was necessary for most patients [14]. Technology may be rejected due to reluctance to alter current techniques, the improper training of users [15], or simply 
Artigo original

Hegemonia - Revista Eletrônica do Programa de Mestrado em Direitos Humanos, Cidadania e Violência/Ciência Política do Centro Universitário Unieuro

ISSN: $1809-1261$

UNIEURO, Brasília, número 25 (Especial), 2018, pp. 106-135.

because it threatens existing practices [16]. Additionally, many products serve their particular purpose but present an additional problem. For example, replaceable batteries provide power but require a supply chain [17]. It is critical to understand the infrastructure, cultural implications, ease of use, and necessary training and to leave behind all stereotypes and assumptions. Failure to do so has resulted in the failure of many well-intending medical devices that were never able to catch ground.

Healthcare Facilities

Health Technology Management (HTM) policies are also of critical importance for hospitals and other healthcare facilities. The HTM policy dictates the processes for needs assessment, inventory management, and the maintenance and procurement of medical devices. These steps are critical for the success of medical devices in the developing world. A 2004 paper states that medical devices are successfully integrated when there is an official equipment procurement process, as well as personnel training and engineering support [18]. Each of these fit directly under the umbrella of the HTM plan, demonstrating the importance of such procedures. While these aspects of technology management are important in all healthcare settings, very few developing world facilities have an official method for tracking and managing technology assets.

Government involvement from both developed nations and developing nations is critical for successful reform of these practices. Even if medical device manufacturers work to develop technical solutions to meet the needs of these healthcare facilities, reform of the current technology management systems in developing world healthcare facilities is necessary to appropriately procure, maintain, and utilize the newly developed equipment. As many of these healthcare facilities do not have experience in technology management and might be opposed to changes, it will be necessary for national, regional, and local governments to work with facilities to implement these programs. Educating hospital management with a nationally sponsored curriculum would be a tremendous benefit to many facilities. Additionally, international organizations such as the World Health Organizations and the governments of industrialized nations such as the United States and Brazil could work to develop simple and effective standards for such programs. As a starting point, 
Artigo original

Hegemonia - Revista Eletrônica do Programa de Mestrado em Direitos Humanos, Cidadania e Violência/Ciência Política do Centro Universitário Unieuro

ISSN: $1809-1261$

UNIEURO, Brasília, número 25 (Especial), 2018, pp. 106-135.

developing world facilities with no formal HTM policy should begin by implementing formal needs assessment, inventory management, and maintenance procedures.

For existing healthcare facilities that have not yet implemented an HTM, an inventory management system is of primary importance. Naturally, determining the health technology inventory is the first step in establishing an HTM as it outlines what equipment and supplies are available to be managed. The inventory is a working document that should reflect details including type and quantity of all available equipment as well as current operating status, previous maintenance information, and all available procurement and financial information about the device. If any non-functional devices are still in the facility, these should be kept in the inventory spreadsheet and their operational status clearly indicated. Once equipment is officially discarded, it should be immediately removed from the inventory. While this type of information is commonplace in advanced hospitals in the developed world, the majority of developing world facilities do not maintain records of the healthcare technology status at the facility. Additionally, it is critically important to record any accessories including ECG Leads, Electrosurgical Return Pads, etc. The development and upkeep of an inventory management system is critical for the success of the maintenance and needs analysis policies.

In developing a new healthcare facility, the first important aspect of HTM is the needs assessment. The needs assessment process is used to find and fill gaps between the current and ideal state of a facility's technology. For example, in the case of a new hospital, a needs assessment is used to determine what technology should be acquired and how that process should be handled. The needs analysis is necessary at any point at which the equipment inventory or services offered are being reevaluated. As such, the needs assessment is still an essential program for all healthcare facilities - not just new ones. Taking into account the objectives, infrastructure, and human resources of the facility as well as information about the long-term use and end-user of a given technology, informed decisions about the appropriateness of medical equipment can be determined. The needs assessment aids in selecting appropriate technologies by outlining a procedure to thoroughly investigate the intended and unintended impacts associated with a particularly medical device or technology. Figure 4 provides a visual chart of a technology needs assessment summarized in 5 basic questions. 
Artigo original

Hegemonia - Revista Eletrônica do Programa de Mestrado em Direitos Humanos, Cidadania e Violência/Ciência Política do Centro Universitário Unieuro

ISSN: $1809-1261$

UNIEURO, Brasília, número 25 (Especial), 2018, pp. 106-135.

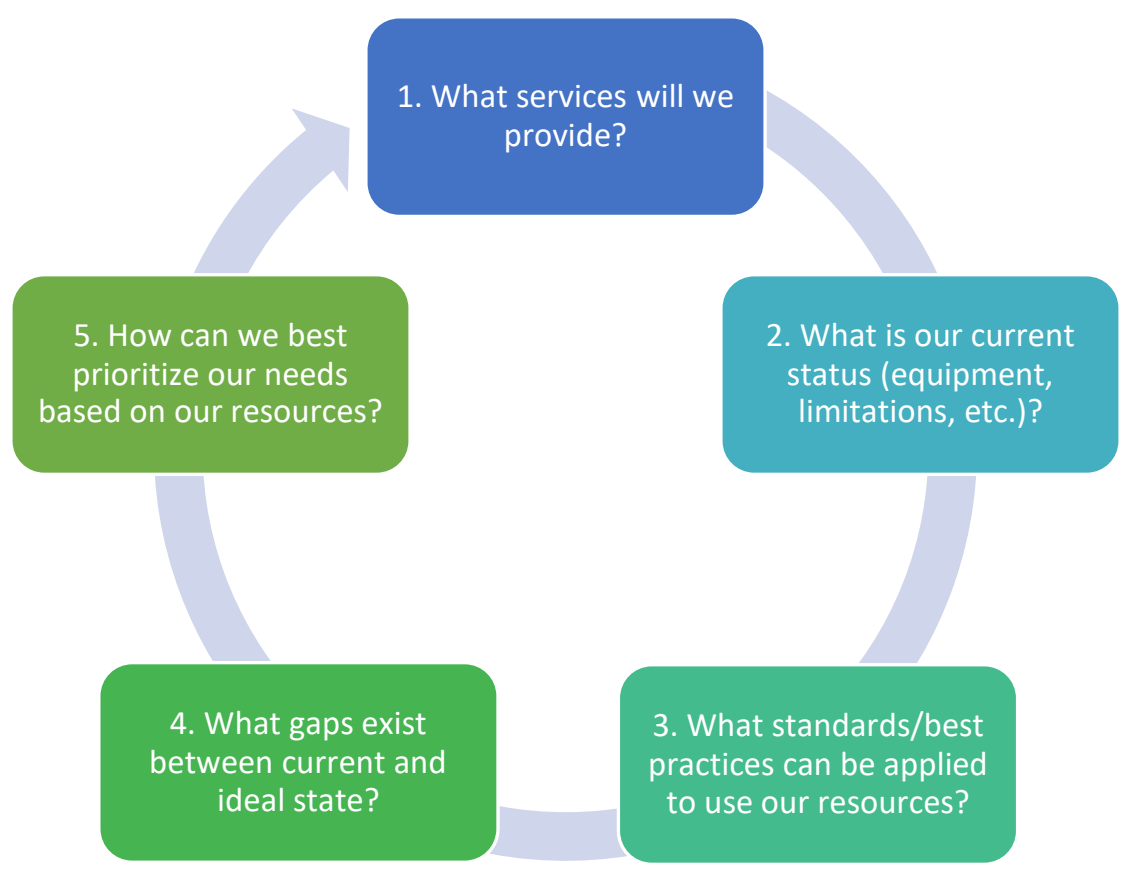

Figure 4 - Questions to consider in a needs assessment (adapted from WHO).

Development of a maintenance strategy is critical to ensure the long-term success of efforts to reduce the technology disparity. Many developing world healthcare facilities do not have trained maintenance technicians despite incredibly harsh equipment operating conditions and the receipt of many nonfunctional medical devices. Some government facilities have trained Biomedical Engineers working on the campus, but many of the rural clinics and district hospitals rely on local repair people with little to no experience with medical device maintenance. As such, nearly none of these healthcare facilities performs even the most basic preventative maintenance procedures, which are critical to the longterm success of the little working medical equipment available. Additionally, many donated devices do not have intuitive alarms, messages, or user-interfaces, so it is common for hospital staff to incorrectly believe that a device is or is not functioning correctly. Given the lack of training and manuals, untrained staff responsible for the repair of equipment often unnecessarily take apart devices to 
Artigo original

Hegemonia - Revista Eletrônica do Programa de Mestrado em Direitos Humanos, Cidadania e Violência/Ciência Política do Centro Universitário Unieuro

ISSN: $1809-1261$

UNIEURO, Brasília, número 25 (Especial), 2018, pp. 106-135.

inspect for visible damage. As the majority of medical devices can be attributed to power supply failures or a faulty accessory, this process of troubleshooting is severely lacking.

While retaining staff for technical maintenance and even the costs of basic training on medical device repairs are expensive, hospitals would save significantly in the long term by extending the operational life of equipment with preventative maintenance and proper troubleshooting. If, however, this is unfeasible for a facility, simple resources by which staff can identify medical devices and easily access basic information about their maintenance (e.g. when to change external air filters) should be acquired. This is, once again, where hospitals should reach out to governing bodies and international organizations for help. Additionally, it is critical that maintenance records be maintained directly alongside the inventory tracking. These together can be used to drive procurement decisions during needs assessment activities. If no additional resources are accessible, even a Microsoft Excel spreadsheet or well-documented hand-kept ledger would serve as a useful method of tracking both inventory and maintenance history.

\section{Technical Design Considerations}

When a medical device is introduced into the developing world market, its success and integration depend on the cultural acceptance of the device as well as on its technical performance [11]. Many technical, economic, and cultural design considerations must be addressed when designing for the developing world. The cultural and economic considerations should primarily be addressed prior to the design in the market and technology assessment and through a change in mindset. A technology development company, Product Development Technologies, presents three major guidelines to negotiate the cultural hurdles, including: understanding the cultural differences in each country, forgetting preconceived notions about product development, and to being flexible [19]. This section focuses primarily on some of the major technical consideration that must be made for medical devices in the developing world. 
Artigo original

Hegemonia - Revista Eletrônica do Programa de Mestrado em Direitos Humanos, Cidadania e Violência/Ciência Política do Centro Universitário Unieuro

ISSN: $1809-1261$

UNIEURO, Brasília, número 25 (Especial), 2018, pp. 106-135.

While not intended as a comprehensive list or a design manual, the following subsections address primary technical challenges and provide the reader with a basic technical understanding of a recommended design approach for each. Each of these factors will be introduced and then related briefly to a design case study. The design case study relates to the development of a modular system used to improve the sustainability of existing medical oxygen concentrator models in the developing world. While medical oxygen concentrators are often the most effective method of oxygen delivery in the developing world, they are subject to a number of critical infrastructure, environmental, and userelated conditions that cause them to fail prematurely. This project, developed by a team of Biomedical Engineering students from Milwaukee School of Engineering in the United States, is intended to provide a modular solution that can be fitted to nearly any existing home-use oxygen concentrator model to improve its sustainability. At time of writing, this project has not yet been brought to market and is not intended to serve as an authority in the field of medical device design, but is rather intended to demonstrate the design considerations made for some of the specific technical challenges encountered in this market.

Power

According to the World Health Organization, inadequate power supply is the single most common cause of medical device failure, accounting for nearly one third of equipment failures [20]. While power is very stable in modern hospitals in the developed world, developing world healthcare facilities often experience both short and long-term power outages as well as significant brownout and overvoltage conditions that challenge medical equipment which was designed for use in a modern healthcare facility. A 64-day study from 2014 at Jinja Regional Referral Hospital in Uganda demonstrated a weekly average of 13 episodes of power failure (measured output less than $200 \mathrm{~V}$ lasting for more than 5 minutes) with a median duration of 30 minutes (ranging from 5 minutes to 17.5 hours) [21]. Although the power conditions at all healthcare facilities are not necessarily this poor, most of these facilities have multiple short-term power outages weekly. Even when power is available, it is often inconsistent 
Artigo original

Hegemonia - Revista Eletrônica do Programa de Mestrado em Direitos Humanos, Cidadania e Violência/Ciência Política do Centro Universitário Unieuro

ISSN: $1809-1261$

UNIEURO, Brasília, número 25 (Especial), 2018, pp. 106-135.

and can be detrimental to modern medical equipment that was designed for use in facilities with highly regulated and extremely consistent power.

Design for such power conditions is relatively straightforward. For small, critical medical devices with low power requirements, battery backup can be considered to allow for operation during short and medium-length power outages. Additionally, circuitry can be designed to provide overvoltage protection and to rectify power during brownout conditions. For many devices, an off-the-shelf Uninterruptible Power Supply (UPS) can both provide short-term battery backup and clean up unclean incoming power. Most medical device manufacturers either have capable internal teams or work with suppliers who are experienced in the design and implementation of power supplies with voltage-rectification and battery backup capabilities. While the overall cost of the device will be slightly increased by such modifications, there is largely not a major technical challenge associated with capable power supplies.

In some cases, batteries are cost- and weight-prohibitive, and there are concerns about the sustainability of batteries, primarily regarding the sourcing and installation when new batteries are required. In many cases where the device is not life sustaining, these concerns can dictate a decision to not provide battery backup. For most devices not directly life-sustaining, battery backup is often an unnecessary expense and liability. For critical care devices, however, it may be necessary to implement a battery-backup system despite higher costs - it is preferable in some facilities to have fewer devices that can operate consistently than to have multiple inconsistent life-sustaining devices. Devices that can operate without power during power outages are often desirable - for example, some ventilators sound an alarm during power outages and then can be hand-operated by a healthcare worker.

Another important consideration to be made with regard to the power supply is power consumption of the device. In many cases in the developing world, low power consumption is desirable as it reduces the burden on the building's power and potentially allows for operation in low-power settings or with small, replaceable or rechargeable batteries. While it is usually beneficial to keep power consumption low, this is not often the case if the technology is life sustaining and if no alternatives are available. For example, medical oxygen concentrators, often requiring more than 300 watts of power, are still 
Artigo original

Hegemonia - Revista Eletrônica do Programa de Mestrado em Direitos Humanos, Cidadania e Violência/Ciência Política do Centro Universitário Unieuro

ISSN: $1809-1261$

UNIEURO, Brasília, número 25 (Especial), 2018, pp. 106-135.

commonly used in developing world healthcare facilities. This is because these concentrators are often still the cheapest and most effective method of oxygen delivery as it is often more difficult to refill oxygen canisters for continuous use outside the operating room.

As existing oxygen concentrator models can be easily modified to make them more sustainable, their high power consumption is not currently of primary concern. Instead, an Uninterruptible Power Supply (UPS) with battery backup for approximately 10 minutes was fit to the device. A number of considerations were made in determining how best to approach the power supply. First, it was clear that voltage regulation was required to prevent damage or substandard operation during brownout or overvoltage conditions. Second, it was determined that battery backup was beneficial as oxygen is often needed in cases of trauma and respiratory failure. The battery capacity was set to provide 5-10 minutes of battery backup - enough to operate continuously through the short power outages experienced on a nearly daily basis. This battery lifespan also provides adequate time to transfer a patient to an oxygen cylinder if necessary during longer power outages. A balance was achieved between cost and battery lifespan by clearly defining customer requirements at the outset and by confirming these specifications with several industry experts and healthcare professionals in the developing world. As oxygen concentrators traditionally operate using a large compressor, it was necessary to use a power supply that could power such a large inductive load - therefore a UPS was chosen with pure sine or "simulated" sine wave output as opposed to "modified" or "PWM" sine wave output. The technical power supply specifications and decisions are very straightforward for experienced electrical engineers at medical device manufacturers and power supply vendors alike and are not a matter of primary concern so long as the infrastructure of the intended use-setting is well understood.

\section{Environment}

Another significant consideration to be made in designing medical devices for use in developing world healthcare facilities is the environmental conditions in which they will be used. Harsh environmental 
Artigo original

Hegemonia - Revista Eletrônica do Programa de Mestrado em Direitos Humanos, Cidadania e Violência/Ciência Política do Centro Universitário Unieuro

ISSN: $1809-1261$

UNIEURO, Brasília, número 25 (Especial), 2018, pp. 106-135.

conditions never experienced in healthcare facilities in the developed world - such as high temperatures, humidity, dust, and numerous impacts - are commonplace in developing world facilities.

As medical devices continue to become more and more technologically advanced and sensitively tuned they become more prone to damage in developing world healthcare facilities if appropriate countermeasures are not taken. Sensitive electrical components are clearly sensitive to heat, humidity, and dust and therefore must be adequately ventilated and protected by effective particle filters. Proper ventilation and the integration of additional fans (along with particle filters) helps to ensure that electrical components do not overheat and cause either permanent damage or substandard operation. This is particularly important for equipment that requires precise operation and has high power consumption (e.g. fluoroscopy units).

One particular issue associated with heat and dust is that bulk particle filters on vents that help to cool devices are often not exchanged or cleaned on a regular basis, if at all. When these filters accumulate enough dust and debris, ventilation is significantly reduced and the devices are far more likely to overheat. While a sustainable solution to this solution has not yet been found in the literature for inclusion in the oxygen concentrator case study, two primary solutions have been proposed. First, the inclusion of very intuitive, language independent messages in the improved user interface (discussed later in this report) will be tested to determine whether it increases the frequency of basic maintenance such as washing or replacing these filters. Another proposed solution would implement a small fan blowing outwards from the device in conjunction with a powerful piezo for haptic feedback embedded within a slightly thicker particle filter to shake dust loose on a set schedule while it is blown away by the fan.

Additionally, particularly for equipment with sensitive electrical components, panels must be sealed in such a way that dust cannot enter freely. Figure 5 shows a dust-filled medical oxygen concentrator from a hospital in Tanzania. While oxygen concentrators do not contain highly sensitive electrical components but the dusty environments can contribute to early failure of the compressor. 
Artigo original

Hegemonia - Revista Eletrônica do Programa de Mestrado em Direitos Humanos, Cidadania e Violência/Ciência Política do Centro Universitário Unieuro

ISSN: $1809-1261$

UNIEURO, Brasília, número 25 (Especial), 2018, pp. 106-135.

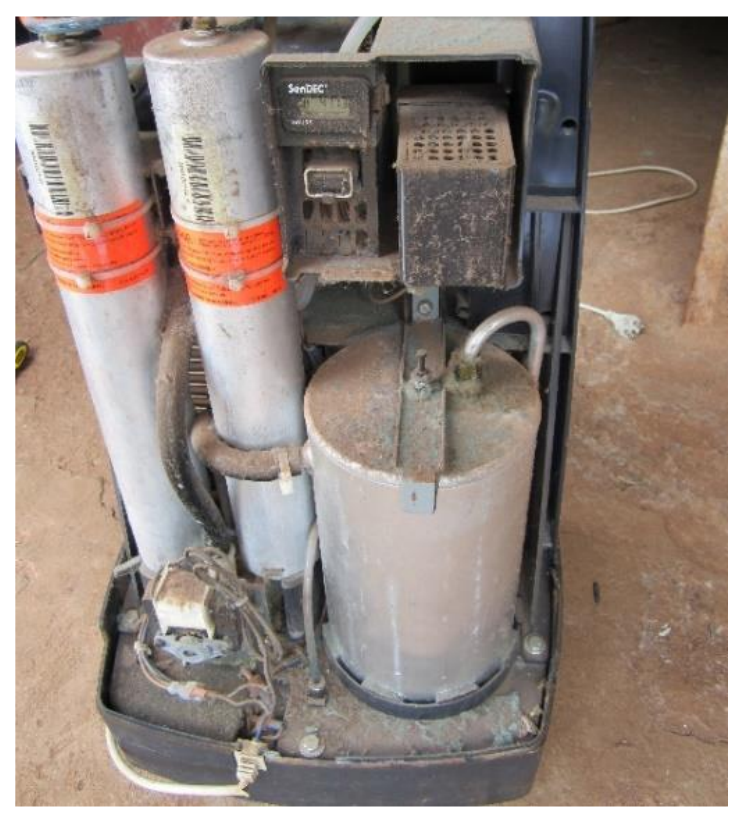

Figure 5 - In certain environments, removal of body panels can reveal the effects of a dusty environment.

Humidity is another environmental factor that can affect the performance of various medical devices. In general, as with dust and heat, humidity can have a detrimental effect on electrical components, particularly if steps are not taken to prevent the condensation of moisture in the air onto the components. In other cases, humidity can affect the operational mechanism of the medical device itself. For example, humidity can significantly reduce the operational lifespan of oxygen concentrators in the developing world. Oxygen concentrators take in room air and compress it in a canister filled with Zeolite, which selectively binds to nitrogen when the air is pressurized. At this stage, the remaining air is approximately $90-95 \%$ and can be delivered to the patient before the Zeolite canister is depressurized, releasing the nitrogen as exhaust. When humid air enters these chambers, the Zeolite binds tightly to the water and does not release it when the canisters are depressurized, ultimately reducing the ability of the device to concentrate oxygen. Over time, the concentrator is no longer able to perform its function, outputting air with an oxygen concentration well below $85 \%$, sometimes as low as $50 \%$. 
Artigo original

Hegemonia - Revista Eletrônica do Programa de Mestrado em Direitos Humanos, Cidadania e Violência/Ciência Política do Centro Universitário Unieuro

ISSN: $1809-1261$

UNIEURO, Brasília, número 25 (Especial), 2018, pp. 106-135.

Depending on the operative mechanism of the technology, considerations such as these must be considered in addition to the traditional environmental factors. In this case study, the goal was to develop a sustainable method to dehumidify inlet air without a need for user intervention, as most facilities do not have trained maintenance staff. The implemented solution utilizes a high capacity, heat-regeneratable desiccant (Drierite) through which all inlet air flows before entering the oxygen concentrator. This passive method takes humid air into the desiccant housing and supplies dry air to the concentrator in order to preserve the Zeolite beds. As the desiccant has a maximum adsorption capacity and would eventually saturate, it was necessary to develop an automated method to regenerate the desiccant without a need for human interaction. A monthly, automated regeneration cycle was implemented using high-power heat tape to heat the desiccant housing to the temperature required for desiccant regeneration. This exhaust air was then redirected away from the oxygen concentrator into the open air. Meanwhile, the airflow is disconnected from the concentrator - and therefore the patient - and the caretaker is notified that the device is locked out and non-operational until the cycle is complete (approximately an hour and a half). This process improves the sustainability by allowing the desiccant to be used and regenerated continuously. While costs to produce prototypes appear prohibitive, high volume manufacturing of such solutions drastically reduces costs and could be very manageable for developing world applications.

As previously mentioned, the design implemented in this case study is clearly not applicable to all medical devices, nor is it necessarily the ideal solution to the issues presented. These designs are simply presented to demonstrate some of the technical challenges facing medical device manufacturers.

Serviceability

As discussed earlier, developed nations have extensive clinical engineering teams in their hospitals and local support for the devices that they purchase. This serves developed healthcare systems well, but in developing nations, this is not the case. Public hospitals will often have a technician on staff who may have a certificate in general maintenance, but certainly no formal engineering training. This creates a 
Artigo original

Hegemonia - Revista Eletrônica do Programa de Mestrado em Direitos Humanos, Cidadania e Violência/Ciência Política do Centro Universitário Unieuro

ISSN: $1809-1261$

UNIEURO, Brasília, número 25 (Especial), 2018, pp. 106-135.

problem when very complex devices, such as imaging equipment, are donated to these areas and undoubtedly break down. A manual may be provided with the donation, but is often in the wrong language or is lost soon after delivery, leaving very little technical support for those tasked with repairing such devices. This is an apparent issue across numerous developing nations, with many devices no longer functioning within the first year of use.

It has become commonplace for manufacturers of any device, including medical devices, to create proprietary components on their systems that are unique to their designs in order to ensure continued revenue as users order replacement parts over the lifetime of the device. From an economic standpoint, this makes a lot of sense and allows for longevity of the device and the company. This strategy, however, does not fare well when medical devices are donated to developing countries. If the parts are no longer manufactured by the original company, cost too much, or are only available in select regions of the world, those repairing the devices are out of luck. Similar parts may be available, but lack of such parts is cited as one of the top three reasons that equipment lies idle in developing countries [6].

In order to address the problem of serviceability, the modification of an existing oxygen concentrator aims to make the device even more resistant to failure and breakage. This includes reinforcing the housing overall and replace small, plastic wheels with larger, lockable wheels that can handle more treacherous environments. This ideology was also applied to the dehumidification system within the device that operates an automated regeneration cycle, which removes the need for maintenance and reduces the possibility of human error.

Improvements also include intuitive, language-free maintenance graphics displayed on the user interface (explained in the following section), which allows for a user to understand how the device is failing or see the required actions to perform preventative maintenance without the need of extensive explanations or manuals. 
Artigo original

Hegemonia - Revista Eletrônica do Programa de Mestrado em Direitos Humanos, Cidadania e Violência/Ciência Política do Centro Universitário Unieuro

ISSN: $1809-1261$

UNIEURO, Brasília, número 25 (Especial), 2018, pp. 106-135.

Usability and Human Factors

As with any medical device, designing it in such a manner that its intended users can operate it properly is of utmost importance. In order to carry this out successfully, those engineering the devices must understand who is going to use their device and take careful consideration to predict ways in which the device may be misinterpreted or misused.

Due to the advancement in medical device technology, many devices have extensive setting and operation options, and it becomes the user's duty to interact with those options to ensure proper use and patient safety. There is an increasing amount of documentation supporting the application of both usability engineering (UE) and human factors engineering (HFE) principles to medical devices specifically in order to predict and plan for the interaction between people and the device. The FDA Office of Device Evaluation within the Center for Devices and Radiological Health lays out some of the pivotal considerations for usability, which will be discussed briefly, along with the necessary steps to manage risk on a device that is intended for developing countries specifically [22].

Figure 6 shows a simplified interaction between the key variables for device use and the possible outcomes due to those interactions. In order to properly assess the usability of a device, it is pivotal to understand the environment, user, and user interface along with their individual risks, but furthermore, the interaction of those individual risks that could lead to unforeseen misuse. 
Hegemonia - Revista Eletrônica do Programa de Mestrado em Direitos Humanos, Cidadania e Violência/Ciência Política do Centro Universitário Unieuro

ISSN: $1809-1261$

UNIEURO, Brasília, número 25 (Especial), 2018, pp. 106-135.



Figure 6 - Factors affecting device use and their interaction leading to either proper or improper use (adapted from FDA).

User

One of the most important considerations for devices intended for global use is the intended user's skills and limitations. In the context of a medical device for developing countries, the expertise of nurses, doctors, and possibly technicians in that environment will differ greatly from those in developed nations. It may be safe to assume a certain level of understanding if the device is similar to others already in use in the environment, but a completely new device or user interface must be handled as if the user has no background knowledge. The consideration of intended users must also be explored in conjunction with the possible unintended users that may interfere with the device's operation, which will be discussed further in the layout of a proper usability risk analysis. Understanding the literacy and language skills of the intended users is also of the utmost importance and plays a large role in the development of a user interface, particularly for a global device. 
Artigo original

Hegemonia - Revista Eletrônica do Programa de Mestrado em Direitos Humanos, Cidadania e Violência/Ciência Política do Centro Universitário Unieuro

ISSN: $1809-1261$

UNIEURO, Brasília, número 25 (Especial), 2018, pp. 106-135.

\section{User Interface}

The user interface on a device must take into account of variety of variables that will affect the device's proper use by the intended users. Ideally, the user interface encourages intuitive use and prevents faults through its setup and layout. This includes an understanding of the hardware that the user will be interacting with (buttons, knobs, screen etc.) along with the effected components that the user ultimately has control over. It is also key to understand which accessories are in contact with the patient and how the user interface allows for control of those components. The user interface also takes into account the labeling on the device and supplemental materials that are provided with the device (manual, etc.).

\section{Use Environment}

The intended environment for use of a medical device must also be considered when assessing the overall usability of the device. For developing countries, the clinical environment differs greatly from that in the developed world, which requires background knowledge or research on the typical operating conditions in a district hospital. This includes understanding the lighting and layout of the wards, the typical noise levels in the hospital, along with other devices that may be in use nearby which could confuse or distract the user. With this context properly laid out, it is simpler to work through the necessary design considerations to adapt for low lighting, loud environments, and the like.

In light of these considerations, the goals and limitations of the user interface of an existing oxygen concentrator were analyzed. As various modifications and additions were explored, it was pivotal to ensure the overall use of the concentrator stayed relatively consistent to existing models currently in the field, which clinical and technical staff already have familiarity. This included keeping the power and flow control consistent with the existing device, with only the addition of an LCD screen to track system operation. The display does not take any user input, which eliminates the risk that a user may 
Artigo original

Hegemonia - Revista Eletrônica do Programa de Mestrado em Direitos Humanos, Cidadania e Violência/Ciência Política do Centro Universitário Unieuro

ISSN: $1809-1261$

UNIEURO, Brasília, número 25 (Especial), 2018, pp. 106-135.

get lost in system menus or alters a key setting unknowingly. This display also allows for the display of the supplied oxygen concentration, which is key to understanding if the unit is functioning properly. The screen also allows for the display of multimedia images that can portray system warnings or maintenance assistance without the need for extensive words or sentences that could be lost in language translation.

This is a basic improvement to an existing concentrator and certainly requires some field-testing to determine its efficacy, but it meets the requirements of portraying the proper information to the intended user while minimizing the risk that any of its users could interact with it improperly.

\section{References}

[1] International Trade Administration, "2016 Top Markets Report Medical Devices," 2016.

[2] World Health Organization, "Future public health needs: commonalities and differences between high- and low-resource settings," 2010.

[3] World Health Organization, "Development of medical device policies," WHO, Geneva, 2011.

[4] T. Baker, "Critical Care in Low-Income Countries," Tropical Medicine and International Health, vol. 14, no. 2, pp. 143-148, 2009.

[5] Medical Devices: Fact Sheet 346, World Health Organization, 2010a.

[6] R. Malkin, "Designing Appropriate Healthcare Technologies," Appropriate Technology, vol. 35, no. 4, p. 64, 2008.

[7] "HTA glossary," International Network of Agencies for Health Technology Assessment and Health Tchnology Assessment international, [Online]. Available: http:/ / htaglossary.net/HomePage. [Accessed 15 April 2018]. 
Artigo original

Hegemonia - Revista Eletrônica do Programa de Mestrado em Direitos Humanos, Cidadania e Violência/Ciência Política do Centro Universitário Unieuro

ISSN: $1809-1261$

UNIEURO, Brasília, número 25 (Especial), 2018, pp. 106-135.

[8] GE Healthcare, "New Portable Ultrasound for Developing Nations Launched at World Health Assembly," 19 May 2015. [Online]. Available: http://newsroom.gehealthcare.com/portableultrasound-developing-nations-launched-world-health-assembly/. [Accessed 16 April 2018].

[9] GE Healthcare, "Affordable, Efficient Healthcare Technology in Developing Countries Key to Saving Lives," 18 April 2011. [Online]. Available: http://newsroom.gehealthcare.com/pt-ctdeveloping-countries/. [Accessed 16 April 2018].

[10] Gradian Health Systems, "Universal Anesthesia Machine," 2018. [Online]. Available: https://www.gradianhealth.org/our-products/uam/. [Accessed 18 April 2018].

[11] A. Krishnamurthy and W. Chans, "Design Factors for Medical Device Functionality in Developing Countries," in Proceedings of the 2013 Industrial and Systems Engineering Research Conference, San Juan, 2013.

[12] J. Dyro, "Donation of medical device technologies," in Clinical engineering handbook, Burlington, Elsevier Academic Press, 2004, pp. 155-158.

[13] R. Wood, Worldwide Biomedical Charitable Services: providing technical support and promoting healthcare technology management internationally, Milwaukee, 2017.

[14] R. Hitchkiss, "Wheelchair for the third world in new medical devices: Invention, development and use," National Academy of Engineering, Washington DC, 1988.

[15] J. Dankelman and a. et, "Increasing complexity of medical technology and consequences for training and outcome of care [Background Paper 4 of the Priority Medical Devices project]," World Health Organization, Geneva, 2010.

[16] H. Petkova and e. al., "Barriers to innovation in the field of medical devices [Background Paper 6 of the Priority Medical Devices project]," World Health Organization, Geneva, 2010. 
Artigo original

Hegemonia - Revista Eletrônica do Programa de Mestrado em Direitos Humanos, Cidadania e Violência/Ciência Política do Centro Universitário Unieuro

ISSN: $1809-1261$

UNIEURO, Brasília, número 25 (Especial), 2018, pp. 106-135.

[17] H. Josee and e. al., "Medical Devices: Managing the Mismatch - An outcome of the Priority Medical Devices project," World Health Organization, Geneva, 2010.

[18] M. Lister, "Transfer of Medical Technology to Developing Countries," Indian Journal for the Practising Doctor, vol. 1, no. 2, 2004.

[19] D. D. Medical, "Firm gives tips for developing devices in emerging countries," Tomson Reuters (Scientific) Inc., Seattle, 2010.

[20] R. A. Malkin, "Barriers for medical devices for the developing world," Expert Review of Medical Devices, vol. 4, no. 6, pp. 759-763, 2007.

[21] H. Turnbull, A. Conroy, O. Opaka, K. C. Kain and M. Hawkes, "Solar-powered oxyegn delivery: proof of concept," The International Journal of Tuberculosis and Lung Disease, pp. 1-7, 2016.

[22] FDA Center for Devices and Radiological Health, "Applying Human Factors and Usability Engineering to Medical Devices," 2016.

[23] World Health Organization, "Health Technology Assessment of Medical Devices," World Health Organization Medical Device Technical Series, Geneva, 2011. 